\section{Dr. Anil Chadha}

The most beautiful people we have known are those who have known defeat, known suffering, known struggle, known loss, and have found their way out of the depths. These persons have an appreciation, a sensitivity, and an understanding of life that fills them with compassion, gentleness, and a deep loving concern. Beautiful people do not just happen.

—Elizabeth Kubler Ross

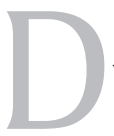

r. Anil Chaddha was one such wonderful person who had compassion for all his Plastic and Reconstructive surgery patients, and a passion deep and direct from the heart, for treating burn injuries and Hansen's disease, for he believed rightly that these were neglected areas in Plastic Surgery. It is to his credit that he played a key role in restoring and reclaiming burns management into the mainstream of Plastic Surgery at a time when many programmes did not include burn injuries in the mainstream curriculum.

He was a teacher par excellence; he had the right combination of academic prowess, clinical acumen and surgical skills. Besides he had a way with his choice of words and his command over the English language was simply superb.

He was a master in his field and could correct clefts with such a flair that it had to be seen to be believed. He was a master craftsman when it came to surgery of the palate, and we would watch him with amazement, deftly closing a palate which we thought was a chasm that could not be bridged with human efforts.

Hand surgery was his forte and we use to watch with awe, his skills, while doing complex tendon transfers or complicated post burn or Hansen contractures of the digits, with an elan and ease and demonstrate to his students by training them, even holding their hands and guiding them through the procedure.

To his students he was much more than a teacher, and he in turn, regarded all of them as his children. He always listened to them and gave them solutions which were simple and practical. He was a fantastic thinker and a voracious reader and his thirst for knowledge and his depth and extent of knowledge was so vast that he was considered as a living encyclopedia of Plastic Surgery.

He was a perfectionist and would not publish any scientific article till he was completely satisfied; suffice it to say that if we could have our scientific writings edited and approved by him, they would be accepted anywhere in the world-such was his expertise and knowldege. He always believed that we should wait for the froth to be settled before giving new technology an approval, because he cared deeply for his patients and students.

He was not satisfied with his academic prowess or his surgical skills alone; he wanted to explore new horizons, and realms of possibilities of the human mind. His knowledge and experience were uniquely tempered with humane compassion and a sense of doing the right thing in every situation consistently-this was the hallmark of his existence.

He was a born leader and people respected him and his work across the board. He showed his mettle in handling crisis situations like the massive earthquake and riots in Gujarat. During his tenure as superintendent of Civil Hospital, several world leaders visited the earthquake victims at Civil Hospital, which included the likes of Bill Clinton.

He was a great inspiration to all of us not only during our student days but also throughout his career. He showed us how to fight adversity, and carry on in life doing good, without showing any form of negativism. In his later years he had fought cancer and beaten it totally, and when the time came he knew how to go peacefully. He was not the one who wanted to cling on to life. He had lived it on his terms with unflinching dignity and commitment to his work. He was a lesson for us in life, both in success and in adversity. 
The ultimate measure of a man is not where he stands in moments of comfort and convenience, but where he stands at a time of challenge and controversy.

\section{—Dr. Martin Luther King Jr.}

Dr. Chadha taught us not only plastic surgery but also many valuable lessons in life mainly centering on compassion, credibility, truthfulness, honesty, and a 'never say impossible' attitude. He was a giant of a man and the way he lived his life was admirable. Underpromise and overdeliver, was his mantra, which he passed on to his students. All his students spread out all over India and abroad will always remember him as a mentor who taught not only plastic Surgery but also but also greater life lessons that guided them to success.

Dr. Anil Chadha changed lives positively of his patients and students even anyone who looked up to him. May he rest in eternal peace.
You gain strength, courage, and confidence by every experience in which you really stop to look fear in the face. You must do the thing which you think you cannot do.

—Eleanor Roosevelt.

\section{Ayyappan Thangavel}

Department of Plastic and Cosmetic Surgery, SAL Hospitals and Research Institute, Ahmedabad, Gujarat, India

Address for correspondence: Dr. Ayappan Thangavel, Director and Head of Plastic Surgery, SAL Hospitals and Research Institute, Ahmedabad, Gujarat, India. E-mail: iapan@rediffmail.com

\begin{tabular}{|l|l|}
\hline \multicolumn{2}{|c|}{ Access this article online } \\
\hline Quick Response Code: & \\
\hline & Website: \\
\hline
\end{tabular}

